\title{
De oprichting 2.0, oftewel de digitale oprichting van de BV
}

\author{
Mr.J. van der Weele*
}

\begin{abstract}
Op grond van Europese regelgeving moet het binnenkort mogelijk zijn een $B V$ door middel van een elektronische notariële akte op te richten. Een fysieke bijeenkomst bij de notaris is dan in beginsel niet meer nodig. In de Wna wordt een nienwe titel Va toegevoegd, waarin deze elektronische akte wordt geïntroduceerd.
\end{abstract}

\section{Inleiding}

Op 15 juni 2021 is het ambtelijk voorontwerp (hierna: voorontwerp) voor de wetswijziging die nodig is voor de implementatie van Richtlijn (EU) 2019/1151 in diverse wetten in consultatie gebracht. ${ }^{1}$ Het voorontwerp valt uiteen in vier artikelen, waarbij het eerste artikel de voorgestelde wijzigingen in Boek 2 BW behandelt en het tweede artikel de beoogde veranderingen in de Wet op het notarisambt (Wna) de revue laat passeren.

Naar mijn mening ademt het voorontwerp uit dat het met enige (en wellicht te veel) haast is geschreven. En haastige spoed is zelden goed, zo luidt een bekend Nederlands gezegde. Deze haast blijkt onder meer uit een aantal storende schrijf- en verwijzingsfouten en uit een datum die onjuist in de toelichting is vermeld.

In deze bijdrage zal ik de hoofdlijnen van het voorontwerp behandelen. Daarbij streef ik geen volledigheid na, niet in de minste plaats omdat er ongetwijfeld nog wel een en ander aangepast zal worden in de definitieve tekst. Bovendien is niet ieder onderdeel van het voorontwerp en de toelichting daarop even interessant. Op een aantal kleine onderdelen na zal ik de voorgestelde wijzigingen in het $\mathrm{BW}$ achterwege laten. Ik zal ook niet ingaan op de wijzigingen in de Handelsregisterwet en het Handelsregisterbesluit die de implementatie van de richtlijn met zich brengt. Ik concentreer mij op de formele aspecten van het digitale oprichtingsproces, derhalve die welke voortvloeien uit de Wna. Omdat dit voor een goed begrip van het

\footnotetext{
Mr. J. van der Weele werkt als notaris bij Hak \& Rein Vos juridisch adviseurs en notarissen te Lelystad en is als buitenpromovendus verbonden aan de Radboud Universiteit Nijmegen.

1 Zie www.internetconsultatie.nl/onlineoprichtingbeslotenvennootschap pen. Voluit: Wijziging van Boek 2 van het Burgerlijk Wetboek en de Wet op het notarisambt in verband met de implementatie van Richtlijn (EU) 2019/1151 van het Europees Parlement en de Raad van 20 juni 2019 tot wijziging van Richtlijn (EU) 2017/1132 met betrekking tot het gebruik van digitale instrumenten en processen in het kader van het vennootschapsrecht (PbEU 2019, L 186).
}

voorstel belangrijk is, sta ik ook stil bij het oprichtingsbegrip uit de richtlijn. Ook het bestuursverbod bespreek ik, om vervolgens over te stappen naar de voorgestelde wijzigingen in de Wna. Ik sluit af met een conclusie.

\section{Implementatie van de richtlijn}

Het wetsvoorstel is een rechtstreeks gevolg van de verplichte implementatie van Richtlijn (EU) 2019/1151 van 20 juni 2019. ${ }^{2}$ Deze richtlijn is in werking getreden per 31 juli 2019. ${ }^{3}$ Vervolgens is de lidstaten een termijn van 24 maanden gegund voor implementatie in nationale wetgeving, zodat deze termijn per 1 augustus 2021 is verstreken. ${ }^{4}$ In de toelichting op het voorontwerp is overigens een verkeerde datum van implementatie vermeld:

'Op grond van artikel 2, eerste lid, van de richtlijn dient de richtlijn uiterlijk 21 augustus 2021 omgezet te zijn.’

Dat moet 1 augustus 2021 zijn en niet 21 augustus 2021. Ook in recent verschenen literatuur is die vergissing gemaakt. ${ }^{6}$

Voor lidstaten bestond de mogelijkheid om uitstel te verzoeken wanneer zij moeilijkheden zouden ervaren bij de omzetting in nationale wetgeving. Dat uitstel was dan mogelijk voor maximaal één jaar en alleen voor de termijn bedoeld in artikel 2 lid 1 van de richtlijn. Het voornemen om van de mogelijkheid van uitstel gebruik te maken moest uiterlijk 1 februari 2021 bij de Europese Commissie - met objectieve redenen omkleed - binnen zijn. Nederland heeft gebruik gemaakt van die mogelijkheid en heeft uitstel verleend gekregen voor de duur van één jaar.

2 Zie eur-lex.europa.eu/legal-content/NL/TXT/PDF/?uri=CELEX: 32019L1151\&from=nl. Waar in deze bijdrage wordt verwezen naar artikelen uit deze richtlijn, vermeld ik enkel 'richtlijn'.

3 Art. 4 richtlijn.

4 Art. 2 lid 1 richtlijn. Overigens is het zo dat voor een aantal specifieke onderdelen uit de richtlijn een latere verplichte implementatie geldt, namelijk 1 augustus 2023. Dit betreft onder meer de regeling over de bestuursverboden, waarover later in deze bijdrage meer.

5 MvT op het voorontwerp van wet, p. 1. Waar in deze bijdrage gerefereerd wordt aan 'toelichting', wordt daarmee de MvT op het voorstel bedoeld.

6 T. Salemink \& P.T.J. Wolters, Voorontwerp online oprichting besloten vennootschappen, Ondernemingsrecht 2021/82. In een medio 2021 in WPNR verschenen artikel van de hand van beide auteurs vermelden zij de juiste implementatiedatum. 


\section{Maandblad}

Ondernemingsrecht

De richtlijn zelf is gebaseerd op artikel 50 Verdrag betreffende de werking van de Europese Unie (VWEU), welk artikel is opgenomen in hoofdstuk 2 VWEU, alwaar de vrijheid van vestiging geregeld is. ${ }^{7}$ De richtlijn heeft dus tot doel om de vrijheid van vestiging binnen de EU te vereenvoudigen. Strikt genomen ziet de richtlijn dus niet op de situatie dat er sprake is van een oprichting door iemand die buiten de EU woont c.q. gevestigd is. Het voorontwerp gaat wat dat betreft evenwel verder dan de richtlijn voorschrijft; hoewel het openstellen van de mogelijkheid tot digitale oprichting van een $\mathrm{BV}$ voor personen van buiten de EU naar de letter van de richtlijn een nationale beleidsvrijheid is, kiest Nederland er blijkens het voorstel voor dit wel te faciliteren. De wetgever onderbouwt dit in de toelichting op het voorontwerp door aan te geven dat digitaliseren niet stopt bij landsgrenzen, dat onderscheid naar nationaliteit van oprichters lastig werkbaar zal zijn, en dat daarmee bovendien de aantrekkelijkheid van Nederland als vestigingsland intact blijft. Terecht stelt de wetgever in de toelichting op het voorontwerp dat dat onverlet laat dat een ingezetene van buiten de EU ook zal dienen te beschikken over een in de EU erkend elektronisch identificatiemiddel teneinde gebruik te kunnen maken van de mogelijkheid tot digitale oprichting. ${ }^{8}$

\section{Oprichting van vennootschappen volgens de richtlijn}

Op grond van artikel 13 octies lid 1 van de richtlijn hebben de lidstaten de verplichting te voorzien in een volledige online oprichting door een cliënt, zonder dat deze in persoon moet verschijnen bij een autoriteit, andere persoon of instantie die op grond van het nationale recht gemachtigd is om een onderdeel van de oprichtingsprocedure te behandelen. De richtlijn verwijst daarvoor naar de in bijlage IIA bij de richtlijn vermelde vennootschappen. Voor Nederland betreft dat de BV. Het is de lidstaten op grond van de richtlijn toegestaan om voor andere vennootschappen dan die welke zijn opgenomen in bijlage IIA ook te voorzien in online oprichtingsprocedures. Voor die mogelijkheid heeft onze nationale wetgever niet gekozen in het voorontwerp met als argument dat eerst bekeken wordt of de elektronische oprichting voor BV's goed werkt. Bij positieve beantwoording kan het online oprichtingsproces dan ook worden toegepast voor de NV.

De term 'oprichting' zoals hiervoor bedoeld en zoals die ook door de wetgever is bedoeld in het voorontwerp ziet op het proces voor zover zich dat bij de notaris voltrekt. Dit is vooral van belang omdat de richtlijn een definitie van het oprichtingsbegrip hanteert die niet alleen ziet op het proces bij de notaris: ${ }^{9}$

'het volledige proces van oprichting van een vennootschap overeenkomstig het nationale recht, waaronder het opstellen van de oprichtingsakte van de vennootschap en alle no-

\footnotetext{
7 Zie ook J. van der Weele, Digitale oprichting van kapitaalvennootschap pen en de rol van de notaris, WPNR 2020, afl. 7266, p. 38 e.v.

8 Zie over het elektronisch identificatiemiddel ook hierna in par. 6.

9 Art. 13 bis lid 4 richtlijn.
}

dige stappen met het oog op opname van de vennootschap in het register'.

De richtlijn hanteert dus een ruimer oprichtingsbegrip. Volgens ons recht ontstaat een rechtspersoon door een door een notaris ondertekende akte. ${ }^{10}$ De inschrijving in het handelsregister is dus geen constitutief vereiste voor het ontstaan van een rechtspersoon. ${ }^{11}$ In de meeste ons omringende landen wordt een dergelijk vereiste wél gesteld voor het verkrijgen van rechtspersoonlijkheid. ${ }^{12}$ Hoewel de verantwoordelijkheid voor een tijdige inschrijving in het handelsregister van de eenmaal opgerichte rechtspersoon berust bij het bestuur daarvan, leert de gangbare (notariële) praktijk dat de notaris zorg draagt voor die inschrijving. Ik zou ervoor willen pleiten om die feitelijke gang van zaken ook in de wet te verankeren en de inschrijving van alle rechtspersonen in het handelsregister als een constitutief vereiste voor het ontstaan daarvan te stellen.

\section{Bestuursverbod}

Op grond van de richtlijn moeten lidstaten beschikken over regels betreffende bestuursverboden, welke regels onder meer voorzien in de mogelijkheid om rekening te houden met een van kracht zijnd bestuursverbod of met informatie die relevant is voor het opleggen van een bestuursverbod in een andere lidstaat. ${ }^{13}$ Uit de richtlijn volgt dat het moet gaan om personen die 'de bevoegdheid hebben de vennootschap ten opzichte van derden te verbinden en haar in rechte te vertegenwoordigen'. Nederland heeft de regeling van het bestuursverbod sinds 1 juli 2016 in de Faillissementswet opgenomen in artikel 106a tot en met 106e. Op grond van deze regeling kan een rechter een bestuursverbod uitspreken ten aanzien van zowel bestuurders als feitelijk beleidsbepalers.

In zoverre behoeft het onderdeel dat ziet op het instellen van regels over een bestuursverbod dus geen implementatie meer in onze nationale wetgeving; onze wetgeving voldoet al (ruimschoots) aan die minimumstandaard.

De richtlijn bepaalt verder dat lidstaten van personen die bestuurder willen worden, kunnen eisen dat deze verklaren of zij op de hoogte zijn van omstandigheden die kunnen leiden tot een bestuursverbod in de desbetreffende lidstaat. Bovendien hebben lidstaten volgens de richtlijn de mogelijkheid om de benoeming van een persoon als bestuurder te weigeren als aan die persoon een bestuursverbod is opgelegd in een andere lidstaat. ${ }^{14}$ Dit betreft dus opties waarvan de individuele lidstaten gebruik kunnen maken. Nederland heeft van die beide opties

10 Art. 2:4 BW. Dit is iets anders dan een 'notariële akte'; immers, ook wanneer er geen sprake is van authenticiteit, ontstaat de rechtspersoon.

11 Ik ga uit van de privaatrechtelijke rechtspersonen als bedoeld in Boek 2 BW.

12 Zie ook L. Timmerman \& Chr.M. Stokkermans, Oprichten zonder omwegen. Digitalisering en fraudebestrijding als game changers voor de oprichtingsprocedures van vennootschappen (IVOR nr. 119), Deventer: Wolters Kluwer 2020, p. 47-71.

13 Art. 13 decies lid 1 richtlijn.

14 Art. 13 decies lid 2 richtlijn. 
gebruik gemaakt en introduceert in dat verband een nieuw artikel 2:175a lid 6 en $7 \mathrm{BW}$ in het voorstel. In de toelichting verdedigt de wetgever de introductie van deze regelingen als volgt:

'Het is goed dat met dit wetsvoorstel de mogelijkheid van online oprichting van BV's een plek krijgt in het BW en de Wna. Maar oprichting langs elektronisch [dit moet zijn elektronische; JvdW] weg brengt ook risico's mee. Derden die handelen met de nieuw opgerichte vennootschap moeten worden beschermd en frauduleus of ander wangedrag moet worden voorkomen (overweging 23 van de richtlijn).'

De wetgever stelt daarom voor om personen die zich bij de online oprichting willen laten benoemen tot bestuurder, te laten verklaren of aan hen een bestuursverbod is opgelegd in een andere lidstaat op een van de gronden zoals vermeld in het voorgestelde artikel 2:175a lid 6 BW.

Bij de voorgestelde regeling rijst een aantal vragen. Ten eerste de vraag naar de effectiviteit van de desbetreffende regeling. ${ }^{15}$ Mij doet dit denken aan 'Wij van WC-eend ...': het is maar de vraag of een beoogd bestuurder de verzochte verklaring naar waarheid aflegt. Salemink en Wolters wijzen in het kader van de vraag naar de effectiviteit nog op het risico dat de beoogd bestuurder ten onrechte oordeelt dat zijn situatie niet onder een van de gevallen als opgesomd in artikel 2:175a lid 6 BW (voorstel) valt. Hoewel dat natuurlijk zeker mogelijk is, zie ik daar niet een reëel risico ontstaan. Daar is immers de notariële Belehrung voor. De notaris is verplicht om zijn cliënten deugdelijk voor te lichten, aan die verplichting brengt de introductie van een elektronische notariële akte geen wijziging. Voorlichting over het bestuursverbod is naar mijn mening onderdeel van de Belehrungspflicht.

Ten tweede is het maar zeer de vraag of de notaris enige mate van controle kan uitvoeren op de afgelegde verklaring. De richtlijn bepaalt weliswaar dat er een uitwisseling van gegevens mogelijk moet zijn met behulp van gekoppelde registers, maar de desbetreffende regeling behoeft niet eerder dan 1 augustus 2023 te zijn geëffectueerd. ${ }^{16}$ Pas wanneer die koppeling is gerealiseerd, kan de notaris zelf een controle uitvoeren of een bestuursverbod in een andere lidstaat is opgelegd. Een verklaring van de beoogd bestuurder is dan dus niet meer nodig bij een elektronische oprichting. Tot dat moment zal de notaris het dus nog moeten doen met een verklaring van de desbetreffende bestuurder, welke verklaring als zodanig naar mijn mening overigens weinig toegevoegde waarde heeft (het ' $\mathrm{W}_{\mathrm{ij}}$ van WC-eend'-gehalte). ${ }^{17}$

15 Zie in gelijke zin Salemink \& Wolters 2021.

16 Zie noot 4 .

17 Wellicht dat een verklaring bezien in het licht van de beroepsaansprakelijkheid van de notaris nog wél toegevoegde waarde kan blijken te hebben.
Ten derde vraag ik mij af waarom de hiervoor geschetste verklaring van een beoogd bestuurder alleen nodig zou moeten zijn bij een online oprichting. Waarom niet ook in de situatie van de 'ouderwetse' manier van oprichten? ${ }^{18}$ Weliswaar is klipen-klaar dat de mogelijkheid van online oprichting van BV's risico's met zich brengt, maar dat wil natuurlijk niet zeggen dat diezelfde risico's er niet zouden zijn bij de 'offline' oprichting. Het staat de notaris overigens vrij om een dergelijke verklaring ook bij de ouderwetse manier van oprichting te verlangen, maar naar mijn mening zou het aanbevelenswaardig zijn wanneer de wetgever die verplichting óók in de wet opneemt, zodat er in dat opzicht geen verschil ontstaat met de huidige papieren oprichtingsprocedure die als zodanig blijft bestaan. Die verplichting geldt immers niet voor de situatie dat de BV wordt opgericht op de huidige manier. En wat zou erop tegen zijn om ook voor een 'offline oprichting' in de wet op te nemen dat een check dient plaats te vinden in de gekoppelde internationale registers zoals hiervoor bedoeld?

\section{De notariële vorm blijft}

Voorop staat dat de richtlijn geen afbreuk doet aan nationale rechtstradities. De richtlijn formuleert het als volgt:

'Deze richtlijn doet geen afbreuk aan nationale wetten op grond waarvan een autoriteit, persoon of instantie overeenkomstig de rechtsstelsels en rechtstradities van de lidstaten wordt aangewezen die krachtens het nationale recht gemachtigd is om een bepaald aspect van de procedure voor online oprichting van vennootschappen, online registratie van bijkantoren of online indiening van documenten en informatie te behandelen. ${ }^{19}$

Ook nationaalrechtelijke procedures en voorschriften, zoals die bijvoorbeeld voortvloeien uit de Wna, en de nationale regels over authenticiteit, nauwkeurigheid en betrouwbaarheid hoeven volgens de richtlijn geen wijziging te ondergaan. ${ }^{20}$

Kortom, alle bestaande nationale regelingen omtrent de autoriteit die belast is met de oprichting, de van toepassing zijnde oprichtingsprocedures en de regels omtrent onder meer de mate van authenticiteit hoeven niet te worden gewijzigd. De enige voorwaarde die gesteld wordt in de richtlijn is dat een volledige online procedure voor oprichting mogelijk wordt gemaakt. Het notariaat kan opgelucht ademhalen.

\section{De wijzigingen in de Wna}

In paragraaf 5 is aan de orde gekomen dat de richtlijn geen wijzigingen vereist voor wat betreft nationale procedures en voorschriften met betrekking tot de persoon die bevoegd is tot oprichting. Evenmin doet de richtlijn afbreuk aan de nationale vormvoorschriften voor het ontstaan van de rechtspersoon. Dat neemt niet weg dat de implementatie van de richtlijn in onze nationale wetgeving wijzigingen noodzakelijk maakt

18 Zie in gelijke zin Salemink \& Wolters 2021

19 Art. 13 quater lid 1 richtlijn.

20 Art. 13 quater lid 2 en 3 richtlijn. 


\section{Maandblad}

Ondernemingsrecht

voor wat betreft de vorm waarin de akte opgemaakt moet worden. Immers, onder de huidige Wna is de notariële akte een papieren aangelegenheid. In de Wna moeten dus wijzigingen komen voor wat betreft de wijze van oprichting. Daartoe wordt in de Wna de elektronische notariële akte geïntroduceerd. Er wordt een nieuwe titel Va toegevoegd aan de Wna, getiteld: 'De elektronische notariële akte'. In de toelichting op het voorstel is aangegeven dat de overige bepalingen uit de Wna onverkort toepassing vinden op de elektronische akte, behoudens voor zover bepaalde artikelen uit de Wna expliciet zijn uitgesloten. Ook bevat titel Va Wna bepalingen die juist een verduidelijking bieden op de overige bepalingen uit de Wna als ze worden toegepast op de elektronische notariële akte, aldus de toelichting. ${ }^{21}$ Met inachtneming hiervan zal ik hierna artikelsgewijs de belangrijkste wijzigingen van de Wna nader bespreken.

\subsection{Definitiebepalingen}

In artikel 53a Wna (voorstel) wordt een aantal nieuwe definities geïntroduceerd die relevant zijn in het kader van de elektronische notariële akte. Zo wordt onder meer een definitie gegeven van 'elektronisch identificatiemiddel'. Daarvoor komen twee soorten identificatiemiddelen in aanmerking:

1. een elektronisch identificatiemiddel dat is uitgegeven op grond van een stelsel voor elektronische identificatie dat door Nederland is goedgekeurd;

2. een elektronisch identificatiemiddel dat is uitgegeven in een andere EU-lidstaat op grond van een stelsel voor elektronische identificatie en dat ten behoeve van de grensoverschrijdende authenticatie is erkend overeenkomstig de eIDAS-verordening. ${ }^{22}$

De richtlijn bepaalt dat het de individuele lidstaten vrijstaat om elektronische identificatiemiddelen niet te erkennen als het betrouwbaarheidsniveau daarvan niet voldoet aan het bepaalde in artikel 6 lid 1 eIDAS-verordening. Nederland heeft gekozen voor betrouwbaarheidsniveau 'hoog'. Voor dit type elektronisch identificatiemiddel wordt als eis gesteld dat er technische procedures aan ten grondslag liggen die tot doel hebben om het risico van misbruik of wijziging van identiteit te voorkomen. ${ }^{23}$

\subsection{Van toepassing op een elektronische oprichting}

Artikel 53b Wna (voorstel) bepaalt dat titel Va Wna (voorstel) van toepassing is op een elektronische oprichting van een BV, als bedoeld in artikel 2:175a lid $1 \mathrm{BW}$ (voorstel). Dat artikellid luidt als volgt:

21 Dit staat niet als zodanig in art. 53b Wna (voorstel) te lezen.

22 Verordening (EU) 910/2014 van het Europees Parlement en de Raad van 23 juli 2014 betreffende elektronische identificatie en vertrouwensdiensten voor elektronische transacties in de interne markt en tot intrekking van Richtlijn 1999/93/EG (PbEU 2014, L 257).

23 Art. 8 lid 2 eIDAS-verordening bepaalt dat er drie niveaus van betrouwbaarheid zijn: laag, substantieel en hoog. Nederland kiest dus voor het hoogste niveau van betrouwbaarheid. De betrouwbaarheidsniveaus laag en substantieel stellen als eis dat er technische procedures zijn die het risico van misbruik of wijziging van identiteit verkleinen.
'Een vennootschap kan worden opgericht langs elektronische weg. ${ }^{24}$

Volgens het bepaalde in lid 2 is de notariële akte dan elektronisch. ${ }^{25}$

\subsection{Aanwijzing model oprichtingsakte}

De richtlijn schrijft voor dat de EU-lidstaten moeten beschikken over een model voor de oprichtingsakte. ${ }^{26}$ In artikel $53 \mathrm{c}$ Wna (voorstel) wordt daaraan uitvoering gegeven. Teneinde de actualiteit van het model te waarborgen, wordt geregeld dat het bestuur van de Koninklijke Notariële Beroepsorganisatie (KNB) het desbetreffende model aanwijst. Het model wordt gepubliceerd op een openbaar toegankelijk informatieportaal dat door de KNB wordt beheerd. Het model moet bovendien beschikbaar zijn in een officiële taal van de EU, die door zo veel mogelijk grensoverschrijdende gebruikers kan worden begrepen. Voor Nederland zal dat neerkomen op het Engels. Helaas behelst het voorstel nog niet de mogelijkheid om de oprichtingsakte in het Engels te verlijden. ${ }^{27}$ Dat is naar mijn mening een gemis en ik spreek de hoop uit dat de wetgever hiertoe alsnog besluit.

\subsection{Systeem voor gegevensverwerking}

Artikel 53d Wna (voorstel) bepaalt hoe de elektronische omgeving door middel waarvan de notariële akte tot stand komt, eruit moet komen te zien. Het doel van het systeem is dat het verlijden van een notariële akte in elektronische vorm mogelijk gemaakt wordt.

Het is de bedoeling dat de KNB een systeem beheert waarop iedere individuele notaris wordt aangesloten. De wetgever vindt aansluiting op het systeem op vrijwillige basis niet passend, gezien de ministerieplicht. ${ }^{28}$

Uitdrukkelijk is opgenomen dat binnen het systeem voor gegevensverwerking persoonsgegevens worden verwerkt, waaronder het burgerservicenummer (BSN), een en ander voor zover noodzakelijk voor een goede uitvoering van de Wna en de daarop berustende bepalingen. Vermelding van verwerking van het $\mathrm{BSN}$ is volgens de toelichting nodig, omdat verwerking ervan noodzakelijk kan zijn bij het gebruik van elektronische identificatiemiddelen.

24 Hoewel ik de voorgestelde wijzigingen in het BW niet nader bespreek, wil ik hier tóch van de gelegenheid gebruik maken om een kanttekening te maken bij dit voorgestelde artikel. Het artikel spreekt over 'een' vennootschap. Dit is opmerkelijk, omdat art. 2:175 lid $1 \mathrm{BW}$ angeeft dat titel 2.5 BW (die begint met art. 2:175) van toepassing is op 'de' besloten vennootschap met beperkte aansprakelijkheid. Art. 2:175 lid 2 BW heeft het vervolgens over 'de' vennootschap. Ik vind dus dat de keuze voor het lidwoord 'een' in het voorgestelde nieuwe artikel niet consequent is met de reeds bestaande wetgeving.

25 In de toelichting op het voorstel wordt abusievelijk gerefereerd aan art. 53a lid 2.

26 Art. 13 nonies richtlijn.

27 Zie art. 2:176 BW, welk artikel niet gewijzigd wordt.

28 Art. 21 lid 1 Wna. 


\section{Maandblad}

Ondernemingsrecht

Het systeem van gegevensverwerking moet een aantal functionaliteiten mogelijk maken:

1. de ondertekening van de elektronische notariële akte;

2. de identificatie van partijen, getuigen, tolken, gevolmachtigden en - last but certainly not least - de notaris;

3. het tot stand brengen van een online beeld- en geluidverbinding, welke verbinding een 'natuurgetrouwe weergave' moet bieden van hetgeen zich op dat moment afspeelt in de ruimtes waarin de verschijnende personen, getuigen en de notaris zich bevinden;

4. de ondertekening van de elektronische volmacht (zie par. 6.5).

\subsection{Ondertekening van de elektronische akte}

Een notariële akte komt tot stand door ondertekening daarvan. ${ }^{29}$ Artikel 53e Wna (voorstel) bepaalt dat de ondertekening van een elektronische notariële akte plaatsvindt via het systeem voor gegevensverwerking door gebruik te maken van een elektronische handtekening.

Net als onder huidig recht de situatie is, kan een elektronische oprichtingsakte ook door middel van een volmacht worden gepasseerd. Wanneer gebruik wordt gemaakt van een volmacht tot het verlijden van een elektronische notariële akte, dan moet ook de volmacht op elektronische wijze zijn ondertekend via het systeem voor gegevensverwerking. Bijzonder hierbij is wel dat dit uitsluitend kan ten overstaan van de notaris (of diens waarnemer) die de elektronische notariële akte passeert, aldus artikel $53 \mathrm{f}$ Wna (voorstel). Bovendien kan die volmacht alleen worden verleend aan een onder de verantwoordelijkheid van de desbetreffende notaris werkzame persoon. Hoewel dit ook nu al gebruikelijk is bij het verlenen van een volmacht tot oprichting, bestaat bij de huidige wijze van oprichting strikt genomen nog de mogelijkheid dat (ook) volmacht verleend wordt aan iemand anders, bijvoorbeeld een medeoprichter. Op de elektronische volmacht zijn het eerder besproken artikel 53e Wna (voorstel) en het hierna te bespreken artikel $53 \mathrm{~g}$ Wna (voorstel) van toepassing.

Op grond van artikel 44 lid 1 Wna wordt een volmacht tot oprichting die niet behoort tot het protocol van een Nederlandse notaris aan de akte gehecht. Een dergelijke wijze van aanhechting is in geval van een elektronische notariële akte niet mogelijk. Vandaar dat artikel $53 \mathrm{f}$ lid $2 \mathrm{Wna}$ (voorstel) tevens regelt dat een elektronische volmacht aan de elektronische notariële akte wordt gekoppeld.

\subsection{Het vaststellen van de identiteit}

Het vaststellen van de identiteit van de verschijnende personen is erg belangrijk. Als zodanig is het ook geregeld in artikel 39 lid 1 Wna, op grond waarvan is bepaald dat de bij het verlijden van de akte verschijnende partijen en getuigen aan de notaris bekend moeten zijn. Ook is daar geregeld dat wanneer sprake is van een 'eerste verschijning voor de notaris', de nota- ris de identiteit van die persoon vaststelt aan de hand van een document als bedoeld in artikel 1 Wet op de identificatieplicht. Als gebruik wordt gemaakt van de elektronische notariele akte, dan is die wijze van identificatie niet mogelijk. Artikel 53g Wna (voorstel) bepaalt dat de identiteit van de personen die verschijnen, wordt vastgesteld aan de hand van een elektronisch identificatiemiddel via het systeem voor gegevensverwerking. Het 'verschijnen' gebeurt dan niet in fysieke vorm aan de passeertafel van de notaris, maar vindt dan plaats door middel van de directe beeld- en geluidververbinding. Op grond van het voorgestelde artikel 53a Wna wordt het een identificatiemiddel voorzien van een certificaat met betrouwbaarheidsniveau 'hoog'.

In artikel 53g lid $1 \mathrm{Wna}$ (voorstel) is verder nog het volgende te lezen:

'Personen en getuigen kunnen [curs. JvdW] aan de notaris verschijnen door het gebruik van een directe beeld- en geluidverbinding als bedoeld in art. 53d, vierde lid, onderdeel c.'

Wat betekent het woord 'kunnen' in de hiervoor aangehaalde zin uit het voorgestelde wetsartikel? Hieruit mag zeer zeker niet worden afgeleid dat het 'verschijnen' via een deugdelijk functionerende beeld- en geluidverbinding een facultatief element vormt. Blijkens de toelichting op het voorstel heeft de wetgever met het woord 'kunnen' willen aangeven dat men indien gewenst ook fysiek aan de passeertafel mag plaatsnemen. Waar de notaris een dergelijke fysieke verschijning niet mag eisen, mag de cliënt dat blijkbaar wel. De notaris mag alleen dán de fysieke komst naar het notariskantoor verlangen wanneer de notaris vermoedt dat er sprake is van identiteitsfraude of de regels inzake handelingsbekwaamheid of vertegenwoordigingsbevoegdheid niet worden nageleefd. ${ }^{30}$

\subsection{Plaats van het verlijden van de elektronische akte}

Op grond van artikel 40 lid 2 sub e Wna dient de notariële akte onder meer de plaats te bevatten waar de akte is verleden. Als de oprichting plaatsvindt tijdens een fysieke bijeenkomst, dan levert dat geen probleem op. Immers, op dat moment bevindt iedereen zich op dezelfde plaats. Maar wanneer sprake is van een elektronische notariële akte, kan het zomaar zijn dat de oprichter zich niet op dezelfde plaats bevindt als de notaris op dat moment. Om die reden is in artikel 53h Wna (voorstel) bepaald dat de plaats van het verlijden van de elektronische notariële akte de plaats is waar de passerend notaris zich op dat moment bevindt. Dat moet overigens wel een plaats zijn op Nederlands grondgebied. Het is dus niet toegestaan dat de notaris vanaf zijn vakantieadres in het buitenland de akte passeert. 


\section{Maandblad}

Ondernemingsrecht

Wanneer het tijdstip van ondertekening van de akte door de notaris van belang kan zijn, dan wordt dat tijdstip vermeld. ${ }^{31}$ In geval van een elektronische notariële akte volgt vermelding van het tijdstip uit het gebruik van een gekwalificeerd elektronisch tijdstempel. ${ }^{32}$

\subsection{Documentstandaard}

De Wna geeft regels voor het gebruik van het materiaal waarop de inhoud van de akte wordt weergegeven. Bij verordening kunnen daarvoor nadere regels worden gegeven. ${ }^{33}$ Omdat deze regels niet geschreven zijn voor de elektronische notariële akte, bepaalt artikel 53i Wna (voorstel) om in afwijking van vorenbedoelde eisen andere specifieke eisen te stellen. De inhoud van de elektronische notariële akte, van de elektronische volmacht en van andere elektronische bijlagen wordt gesteld bij verordening, waarin een documentstandaard wordt aangewezen. Die standaard dient de betrouwbaarheid, uitleesbaarheid, duurzaamheid en beveiliging tegen onbevoegde wijziging en ongewijzigde reproductie van de inhoud te waarborgen. Ook moet die standaard voldoen aan de meest recente nationale dan wel internationale standaarden. De aanwijzing bij verordening van de documentstandaard moet vervolgens iedere vijf jaar plaatsvinden. Dat betekent uiteraard niet dat iedere vijf jaar een nieuwe documentstandaard moet worden aangewezen. De periode van vijf jaar is voorgesteld om daarmee tot een periodieke toetsing van de tot dan toe aangewezen documentstandaard te verplichten. ${ }^{34}$

Wanneer wordt overgegaan tot het vaststellen van een nieuwe documentstandaard, dan dienen tevens bij verordening regels te worden vastgesteld over de manier waarop de elektronische notariële akte, de elektronische volmachten en overige elektronische bijlagen worden geconverteerd.

\subsection{Wat is expliciet niet van toepassing?}

Een aantal specifieke, praktische, onderdelen van het passeerproces als zodanig is niet van toepassing bij de elektronische manier van oprichten. Artikel 53j Wna (voorstel) geeft daarvan een opsomming:

1. het zetten van de parafen op de beschreven bladen, artikel 43 lid 3, tweede volzin, Wna;

2. vermelding van de reden van verhindering tot ondertekening van de akte, artikel 43 lid 4, derde volzin, Wna;

3. vermelding van het tijdstip, artikel 43 lid 4, vijfde volzin, Wna (zie hiervoor bij art. 53i Wna (voorstel));

4. de mogelijkheid tot het aanbrengen van wijzigingen door de notaris voordat hij tot ondertekening overgaat, artikel 45 lid 1 Wna. In de toelichting op het voorstel wordt als argument daarvoor aangegeven dat die mogelijkheid bij

31 Art. 40 lid 3 Wna.

32 Als bedoeld in art. 3 onderdeel 34 eIDAS-verordening.

33 Art. 41 lid 3 Wna jo. art. 21 lid 1 Archiefwet 1995 jo. Verordening Aktepapier.

34 Gezien het rappe tempo waarin automatisering zich ontwikkelt, vraag ik mij af of de gestelde periode van vijf jaar niet te krap bemeten is. Dit laat ik echter graag over aan de IT-specialisten. een elektronische notariële akte niet voor de hand ligt, omdat tijdens het fysieke passeerproces de akte op eenvoudiger wijze kan worden aangepast;

5. legalisatie van een handtekening door de notaris, respectievelijk legalisatie van de handtekening van de notaris door de president van de rechtbank, artikel 52 lid 2 en 3 Wna. Aangezien op de elektronische handtekening de eIDAS-verordening en de daaruit voortvloeiende regels van toepassing zijn, wordt legalisatie van de elektronische handtekening uitgesloten.

Onder punt 4 hiervoor kwam aan de orde dat artikel 45 lid 1 Wna buiten toepassing is verklaard voor de elektronische notariële akte. Dat artikellid bepaalt dat de notaris voordat hij tot ondertekening van de akte overgaat, wijzigingen mag aanbrengen in de tekst van de akte. Dat mag niet zomaar, daar geeft artikel 45 lid 1 Wna regels voor. Zo moeten doorhalingen gebeuren op een zodanige manier dat de oorspronkelijke tekst leesbaar blijft. Ook moet de gewijzigde tekst in de kant van de desbetreffende bladzijde of aan het slot van de akte worden geplaatst en moet de wijziging worden goedgekeurd. Bij een elektronische akte ligt dat volgens de toelichting minder voor de hand, omdat tijdens het passeerproces de elektronische akte gemakkelijker kan worden aangepast.

In artikel 45 lid 2 Wna is de bevoegdheid van de notaris opgenomen tot het verbeteren van kennelijke schrijffouten en kennelijke misslagen. ${ }^{35}$ Daarvan maakt de notaris een proces-verbaalakte op en brengt een aantekening aan op de oorspronkelijke akte met vermelding van de datum en het repertoriumnummer van de proces-verbaalakte. Een afschrift van de proces-verbaalakte wordt aan partijen toegezonden. Dit onderdeel uit de Wna wordt echter niet gewijzigd. Dit betekent dat niet is voorgeschreven dat het opmaken van de proces-verbaalakte elektronisch hoeft te gebeuren. De toelichting meldt als reden dat dat immers niet noodzakelijk is voor het mogelijk maken van de online oprichting van de BV. In de toelichting valt ook te lezen dat de KNB voornemens is om praktische richtlijnen te geven voor de manier waarop aantekening dient te worden gemaakt op de elektronische notariële akte van de kennelijke schrijffouten dan wel kennelijke misslagen. Op dit punt volgt dus nog verduidelijking.

Waar naar mijn mening ook verduidelijking over dient te komen, is hoe er afschriften en uittreksels moeten worden afgegeven van de elektronische notariële akte. Daarover wordt met geen woord gerept in het voorstel. Ook in de toelichting op het voorstel wordt daar niets over vermeld.

\subsection{En wat kost dat dan ...?}

Op grond van de richtlijn dienen de in rekening te brengen vergoedingen voor de online oprichtingsprocedure transparant te zijn. Ook mogen deze niet op discriminerende wijze

35 Dit betreft de situatie dat ná het passeren de schrijffouten en/of kennelijke misslagen worden ontdekt. Waar art. 45 lid 1 Wna ziet op de situatie tijdens het passeerproces, ziet art. 45 lid 2 Wna op de periode daarna. 


\section{Maandblad}

Ondernemingsrecht

worden toegepast. Artikel 55 lid 1 Wna bepaalt dat de notaris verplicht is om op verzoek van de cliënt een rekening van zijn honorarium en de overige op de zaak betrekking hebbende kosten op te maken. Uit die opgave moet dan blijken op welke wijze het in rekening gebrachte bedrag is berekend. Daarmee wordt al voldaan aan het transparantievereiste zoals bedoeld in de richtlijn. Toch heeft de wetgever gemeend er goed aan te doen om in aanvulling op hetgeen daarover al in de Wna is opgenomen, in artikel 53k Wna (voorstel) te bepalen dat de vergoedingen voor de online oprichting op niet-discriminerende wijze moeten worden berekend. ${ }^{36} \mathrm{Mij}$ is echter onduidelijk wat die bepaling beoogt te regelen. Ook de toelichting biedt geen nadere uitleg. Wordt daarmee wellicht bedoeld dat de oprichting door middel van een elektronische akte niet duurder mag zijn dan de huidige manier van oprichting? Of is bedoeld te regelen dat de kosten voor een oprichter van buiten Nederland niet hoger mogen zijn dan voor een oprichter uit Nederland? Ik heb het idee dat dit artikel beter uit het voorstel kan worden geschrapt.

\section{Afronding}

Met de implementatie van de richtlijn wordt de mogelijkheid geboden om langs elektronische weg een BV op te richten. Om dat mogelijk te maken is een aantal wetswijzigingen noodzakelijk. Het voorstel van wet dat ter consultatie is aangeboden en waarvan de consultatietermijn intussen al is verstreken, biedt daarvoor de nodige houvast. Dat neemt niet weg dat het voorstel van wet op een aantal punten vragen oproept. Zo is het bijvoorbeeld spijtig dat de wetgever het oprichtingsbegrip uit de richtlijn niet in het voorstel heeft overgenomen, zodat inschrijving in het handelsregister een constitutief vereiste voor het ontstaan van de BV wordt.

Met de voorgestelde wijzigingen in de Wna wordt een duidelijk kader gecreëerd waarbinnen de elektronische notariële akte ten tonele verschijnt. Weliswaar ziet het huidige voorstel enkel op de digitale oprichting van de BV, maar door de opzet van de inhoud van titel Va Wna zal de elektronische notariële akte en het door de KNB op te zetten systeem voor gegevensverwerking breder inzetbaar gemaakt kunnen worden. Niet alleen bij de oprichting van rechtspersonen, maar ook op andere rechtsgebieden. Zover is het echter nog niet; eerst maar eens een wettelijke grondslag voor de elektronische akte afwachten.

36 In het voorstel verwijst de wetgever naar een niet-bestaand wetsartikel (art. 55a lid 1 Wna), maar ik veronderstel dat bedoeld zal zijn art. 55 lid 1 Wna. Ook is een woord ('worden') weggevallen. Tot slot wordt in het voorgestelde artikel nog verwezen naar art. 2:175 lid $3 \mathrm{BW}$, dat thans niet bestaat en ook niet zal ontstaan als gevolg van de implementatie van de richtlijn. 